\title{
Motivation to Follow a Career in Dentistry of Students in Three South-East European Countries
}

\section{Motivacija za nastavak karijere u dentalnoj medicini među studentima triju zemalja jugoistočne Europe}

\author{
${ }^{1}$ Faculty of Dental Medicine, University of Sts. Cyril and Methodius, Skopje, Republic of North Macedonia \\ Fakultet dentalne medicine Sveučilišta sv. Cirila i Metoda, Skoplje, Republika Sjeverna Makedonija \\ ${ }^{2}$ Centre for Professional Practice, University of Kent, Medway Campus, Chatham Maritime, Kent, ME4 4AG, United Kingdom \\ Centar za stručnu praksu Sveučilišta u Kentu, Medway Campus, Chatham Maritime, Kent, ME4 4AG, Velika Britanija \\ ${ }^{3}$ Faculty of Philosophy, Institute of Psychology, University of Sts. Cyril and Methodius, Skopje, Republic of North Macedonia \\ Filozofski fakultet - Institut za psihologiju Sveučilišta sv. Cirila i Metoda, Skoplje, Republika Sjeverna Makedonija \\ ${ }^{4}$ Faculty of Dental Medicine, University of Medicine Tirana, Albania \\ Fakultet dentalne medicine Sveučilišta u Tirani, Albanija \\ ${ }^{5}$ School of Dental Medicine, University of Zagreb, Croatia \\ Stomatološki fakultet Sveučilišta u Zagrebu, Hrvatska
}

\section{Abstract}

Objective: To investigate and compare the factors that motivated students to study dentistry in countries with similar background (Albania, Croatia and the Republic of Northern Macedonia) and to assess whether or not their motivation changed during time. Material and methods: In 2014/2015, cross-sectional studies were conducted in state funded dental schools in Tirana (Albania), Zagreb (Croatia) and Skopje (North Macedonia) to assess student views on their career motivation. All dental students from the first, third and final years of study were invited to participate. The participation was voluntary and anonymous. A five-item questionnaire was translated into languages of the participating countries. Ethics approval was granted by the Ethics Committee of the University of Saints Cyril and Methodius, Skopje. The Chi square test was used to test if there were statistically significant differences in answers between students in 3 countries, furthermore between years of the study. Results: The total number of respondents was 739 (319 in Tirana, 211 in Zagreb and 208 in Skopje) The differences in the answers between the first-year students from all three countries were statistically significant $\left(X^{2}=82.65 ; p<.01\right)$. The most striking answer was to the question on parents' pressure to study dentistry, which was far more frequent in Tirana (up to $27.7 \%$ ). A "positive image" was the most frequent response from students from Zagreb (up to $79.7 \%$ ), but it declined from the first to the final year in Skopje. There were also significant differences between the schools within the $3^{\text {rd }}$ and final years of study. Conclusions: A positive image of dental profession was the main reason for students studying dentistry at all three schools; as many as $97 \%$ of the students of the final year in Croatia, a member of the European Union (EU). In the two non-EU countries (Albania, North Macedonia) it seemed that dental profession does not have such good status and student expectations are not being fulfilled, especially in Skopje (up to $33.9 \%$ willing to change their vocation and up to $64.5 \%$ lost their motivation to study) One of the strategies to improve the situation could be to include more clinical practice and to better organize the study.
Received: February 18, 2020

Accepted: May 2, 2020

Address for correspondence Ass. Prof. Nikola Petricevic University of Zagreb School of Dental Medicine Gundulićeva 5, 10000 Zagreb, Croatia petricevic@sfzg.hr

Key words

Dental Students; Career Choice; Motivation; South-East European Countries

\section{Introduction}

The choice of a professional career is a critical decision for adolescents as it impacts on their future life. It is influenced mainly by advice from parents, relatives, friends and teachers (1). Societal esteem for the chosen profession, the need for prestige and high social status and income are factors which may also influence an individual's career choice (2).

Students' attitude to selecting their future profession is of great interest to educators and educational systems in many countries. Usually, the motivation and interests for choosing a career are intimately related with the performance of
Uvod

Izbor profesionalne karijere kritična je odluka za adolescente jer utječe na njihov budući život. Na njihovu odluku utječu uglavnom savjeti roditelja, rodbine, prijatelja i nastavnika (1). Društveno poštovanje odabrane profesije, potreba za ugledom te visokim socijalnim statusom i primanjima čimbenici su koji mogu utjecati na odabir karijere pojedinca (2).

Stajalište učenika o odabiru buduće profesije od velikog je interesa i za nastavnike i obrazovne sustave u mnogim zemljama. Obično su motivacija i zanimanje za odabir karijere usko povezani s obavljanjem odabrane profesije u društvu. No vrlo 
the chosen profession in society. However, it is very important for society and its healthcare system to understand the motivations and expectations for choosing dentistry as a profession. The literature suggests that dentistry is still an attractive profession. The reasons for its popularity relate to a positive image for the dental profession and include high social status, self-employment, flexible working hours, financial rewards and others (1 -8).

Studies into dental career motivation have reported that altruism is the main reason for choosing dentistry as a profession, since dentistry is a healing science. A study in Japan and Sweden reported that altruism was dental students' primary motivation (5), as did two other studies, one in Iran (4) and the other in Australia (9).

Many students worldwide are entering dental schools even though in their countries there are many unemployed dentists. For example, in the Republic of North Macedonia there are now four dental schools for a population of 2.1 million and many dentists are unemployed or underemployed with a low level of income. It is therefore curiously that despite this, students still wish to study dentistry. Furthermore, previous research has indicated that dentistry in North Macedonia is currently viewed by dentists as a stressful profession which provides a low level of career satisfaction (10). Notwithstanding this situation about 200 students still enroll in Macedonian dental schools each year $(10,11)$. On the other side, the situation in Croatia is different, the number of students of dentistry is similar (3 public Faculties and 160 new students each year) but the population is double, giving better chance to young colleagues to start their professional carrier. Apart from the fact that the public health still employs dentists, dental tourism is increasing and since the country joined $\mathrm{EU}$ it is possible to work in neighboring countries.

Apart from motivation, it is important to understand the socio-demographic backgrounds of those choosing to study dentistry. One study has reported that among Nigerian students a motive for choosing dentistry as a career was its image as a vehicle for the achievement of personal goals, which included good job opportunities abroad, financial independence, and prestige (12). An Australian study of first year dental students concluded that the majority of students came from middle class families, lived in highly developed socioeconomic areas and had well educated parents in professional or white-collar occupations (13). Most of them lived at home with their parents, who had played a major role in influencing them to take up dentistry (13).

It has also been suggested that some dental students place great emphasis on the financial considerations, such as income and financial security. Factors such as wishing to help people are given a low priority (14).

Thus, it appears that dental student career choice may be motivated by very different factors and variations occur from one population to another $(8,15-17)$. The range of motivating factors may vary over time and between countries. From a sociological perspective, there is a growing recognition that the emerging dentists' workforce has very different expectations from those of earlier generations, with the greatest influence being generational or 'age-related'(18). Eastern Eu- je važno da društvo i njegov zdravstveni sustav razumiju motivaciju i očekivanja pri odabiru stomatologije kao profesije. Literatura sugerira da je stomatologija i dalje privlačna. Razlozi popularnosti odnose se na pozitivnu sliku stomatološke profesije i uključuju visok socijalni status, samozapošljavanje, fleksibilno radno vrijeme, financijsku dobit i slično $(1-8)$.

U studijama o motivaciji za stomatološku karijeru ističe se da je altruizam glavni razlog za odabir te profesije, jer je stomatologija znanost okrenuta liječenju. Istraživači u Japanu i Švedskoj izvijestili su da je altruizam primarna motivacija studenata (5), što su potvrdile i druge dvije studije - jedna u Iranu (4) i druga u Australiiji (9).

Mnogi studenti diljem svijeta upisuju se na stomatološki studij iako je u njihovim zemljama mnogo nezaposlenih stomatologa. Na primjer, u Makedoniji sada djeluju četiri stomatološka fakulteta u populaciji od 2,1 milijun stanovnika, a mnogi su stomatolozi nezaposleni ili nedovoljno zaposleni $s$ niskom razinom prihoda. Zato je zanimljivo da, unatoč tomu, studenti i dalje žele studirati stomatologiju. Nadalje, u dosadašnjim istraživanjima u Makedoniji ističe se da stomatolozi doživljavaju svoju profesiju kao stresnu i da osigurava nizak stupanj zadovoljstva karijerom (10). Bez obzira na to oko 200 studenata i dalje se upisuje na taj studij $(10,11)$. S druge strane, stanje u Hrvatskoj je drukčije - broj studenata je sličan (3 javna fakulteta i 160 novih studenata svake godine), ali populacija je dvostruka, što mladim kolegama pruža bolju mogućnost da pokrenu svoju karijeru. Stomatolozi mogu raditi u javnom zdravstvu i imati ugovorom $s$ državom, u privatnom segmentu je stomatološki turizam povećao opseg posla, a otkako je zemlja ušla u EU može se raditi i u susjednim zemljama.

Uz njihovu motivaciju, važno je razumjeti i socijalno-demografsku pozadinu onih koji se odlučuju na studij stomatologije. U jednom su istraživanju autori pokazali da je motiv za odabir stomatologije kao karijere među nigerijskim studentima bio ugled struke kao sredstvo za postizanje osobnih ciljeva, što je uključivalo i dobre prilike za posao u inozemstvu i financijsku neovisnost (12). U australskom istraživanju u kojemu su sudjelovali studenti stomatologije prve godine, zaključeno je da većina potječe iz obitelji srednje klase, živjeli su u područjima visokih društveno-ekonomskih zbivanja te imali dobro obrazovane roditelje u profesionalnim zanimanjima (13). Većina je živjela kod kuće sa svojim roditeljima i oni su imali velik utjecaj na njih da se bave stomatologijom (13).

Također se sugerira da neki studenti stomatologije stavljaju velik naglasak na financije, poput prihoda i financijske sigurnosti. Zelja da se pomogne ljudima istaknuta je kao prednost struke u pojedinim skupinama studenata (14).

Stoga se čini da odabir karijere može biti motiviran vrlo različitim čimbenicima, a razlike se pojavljuju od jedne do druge populacije $(8,15$ - 17). Raspon motivacijskih čimbenika može se mijenjati s vremenom i između zemalja. Sa sociološkog stajališta, sve je istaknutija razlika u očekivanju između nove i prijašnjih generacija, s najvećim utjecajem koji je generacijski, odnosno povezan je s godinama (18). Istočnoeuropske zemlje prošle su kroz ekonomske i političke promjene koje su utjecale na stomatološku praksu i obrazovanje. Ne- 
ropean countries have gone through economic and political changes that have influenced dental practice and education. Some of the countries are members of the European Union $(\mathrm{EU})$ and the others are still making considerable legislative and economic reforms with a view to becoming members in the future. Even though up to 1990, these countries had almost the same political system there are differences in education, health care and their economies that might influence the prospective students' choices and expectations. Furthermore, in many Eastern European countries several new dental schools have been established in the last ten years, without any central workforce planning.

No previous studies in South Eastern European countries have investigated students' motives for choosing dental education and, if they have there would be the same pattern in the countries in the region.

Against this background, the aim of this study was to investigate and compare the factors that motivated students to study dentistry at one of the State-funded dental schools in three South East European countries (Albania - Tirana, Croatia - Zagreb and Republic of North Macedonia - Skopje) and to assess whether or not their motivation changed between years three and five of their studies. Furthermore, the results, that is, the differences and similarities between students from the three different countries could be compared to define the present differences between ex-socialist countries with similar background, Croatia in the process of transition and the other two countries that are at the beginning of that process. Therefore, the hypothesis was that the reasons to follow the career in dentistry would be similar.

\section{Matherial and Methods}

\section{Participants}

There are 5 dental schools (only one is public) in Albania. In Croatia there are 3 public schools and in North Macedonia there are 4 dental schools (three are public). In the academic year 2014/2015, simultaneous cross-sectional studies were conducted at the Schools of Dental Medicine in Tirana (Albania), Zagreb (Croatia) and Skopje (North Macedonia) to understand student views on their career motivation. These dental schools are the biggest dental schools in each country. All dental students from the first, third and final (fifth in some of the countries and sixth in others) years of study were invited to participate in this study. At the beginning of the questionnaire the students were informed about the aim of the study, that participation was voluntary and confidentiality was assured. Ethical approval was obtained from the Ethics Committee at the Faculty of Dental Medicine, University Ss. Cyril and Methodius in Skopje. The study was conducted in full accordance with the World Medical Association Declaration of Helsinki. All students who participated were over the age of 18 years.

\section{Instrument}

An instrument was developed for the purpose of this study by its authors. While the idea arose from the previous study (6), the questions were modified and adopted for the students from these three South - East European countries (Albania, Croatia and North Macedonia). The questionnaire ke države članice su Europske unije (EU), a druge još uvijek provode važne zakonodavne i gospodarske reforme sa svrhom da to postanu u budućnosti. Iako su do 1990. te zemlje imale gotovo jednak politički sustav, razlike u obrazovanju, zdravstvu i njihovoj ekonomiji mogle bi utjecati na izbor i očekivanja budućih studenata. Nadalje, u mnogim zemljama istočne Europe u posljednjih je deset godina otvoreno nekoliko novih stomatoloških fakulteta, bez ikakva planiranja o potrebi za liječnicima.

$\mathrm{Ni} \mathrm{u}$ jednoj dosadašnjoj studiji u zemljama jugoistočne Europe nije istražena motivaciju učenika za odabir stomatološkog obrazovanja te razlike među zemljama u regiji.

U skladu s tim, cilj ove studije bio je istražiti i usporediti čimbenike koji su potaknuli studente na studij stomatologije u jednoj od državnih stomatoloških škola u trima državama jugoistočne Europe (Albanija - Tirana, Hrvatska - Zagreb i Republika Sjeverna Makedonija - Skoplje) i procijeniti je li se njihova motivacija promijenila između treće i pete godine studija. Uz to, postignuti rezultati između studenata iz triju različitih zemalja mogli bi se usporediti s definiranjem postojećih razlika između bivših socijalističkih zemalja sa sličnim podrijetlom - Hrvatske u procesu tranzicije i drugih dviju koje su na početku tog procesa. Zato je hipoteza da su razlozi za nastavak karijere u stomatologiji slični.

\section{Materijal i metode}

Ispitanici

U Albaniji djeluje pet stomatoloških fakulteta (samo je jedan državni), u Hrvatskoj su tri državna, a u Makedoniji četiri (tri su državna). U akademskoj godini 2014./2015. na stomatološkim fakultetima u Tirani (Albanija), Zagrebu (Hrvatska) i Skoplju (Sjeverna Makedonija) provedena su istodobno poprečno-presječna istraživanja (cross-sectional) kako bi se analizirala stajališta studenata o njihovoj motivaciji za stvaranje karijere u području dentalne medicine. Istraživanjem su bili obuhvaćeni najveći stomatološki fakulteti u svakoj zemlji. Svi studenti stomatologije s prve, treće i završne godine (pete u nekim zemljama i šeste u drugima) pozvani su da se uključe. Na početku sudjelovanja studenti su obaviješteni o cilju istraživanja, da je sudjelovanje dobrovoljno i povjerljivo. Etičko odobrenje dobiveno je od Etičkoga povjerenstva Stomatološkog fakulteta Sveučilišta sv. Ćirila i Metoda u Skoplju. Studija je u cijelosti provedena u skladu s Helsinškom deklaracijom Svjetskoga liječničkog udruženja. Svi studenti koji su sudjelovali bili su stariji od 18 godina.

\section{Instrument}

U svrhu ove studije autori su razvili instrument. Iako ideja proizlazi iz prethodnog istraživanja (6), pitanja su promijenjena i prilagođena studentima iz ovih triju zemalja jugoistočne Europe (Albanija, Hrvatska i Sjeverna Makedonija). Upitnik koji se sastoji od dvaju dijelova (četiri pitanja odno- 
which consisted of two parts: four semi-closed questions for career choice and one for satisfaction with dental education (Figure 1) was given to all the dental students who agreed to take part. The questionnaire was piloted by administering the questions to a small group $(\mathrm{n}=30)$ of second-year students from the dental school in Skopje. It has been concluded that it has excellent comprehensibility and time efficacy. The respondents were asked whether they had experienced any kind of difficulty with understanding or answering the questions after group administration. Such difficulties were not reported. The Croatian and Albanian language versions of the questionnaire were not piloted in such a way and they are translations in the respective languages from the Macedonian version of the questionnaire.

The original questionnaire was translated into the Croatian and Albanian language, using the backward-forward se se na izbor karijere, a jedno na zadovoljstvo stomatološkim obrazovanjem) (slika 1.) ispunili su svi studenti koji su pristali na sudjelovanje. Pilot-studija je obuhvatila malu skupinu $(\mathrm{n}=30)$ studenata druge godine sa Stomatološkog fakulteta u Skoplju. Zaključeno je da ima izvrsnu razumljivost i vremensku učinkovitost. Ispitanicima je postavljeno pitanje jesu li imali poteškoće s razumijevanjem ili odgovorima na pitanja. Takve poteškoće nisu prijavljene. Inačice upitnika na hrvatskom i albanskom jeziku nisu bile uključene u pilot-studiju na takav način, nego su prevedene na odgovarajuće jezike s makedonske verzije upitnika.

Izvorni upitnik preveden je na hrvatski i albanski jezik metodom naprijed-natrag, uz pomoć kolega koji imaju iskustva $s$ razvojem upitnika. Najprije je upitnik preveo profesionalni prevoditelj, koji poznaje stomatološki rječnik i semantiku, zajedno sa stomatologom koji odlično poznaje

1. What motivated you to study dentistry? - (1st year students, 3rd year, final (5th/6th) year) •

Što vas je motiviralo da studirate stomatologiju? - (prva, treća i završna godina studija)

1 - Parents pressure $\bullet$ Pritisak roditelja

2 - Positive image $\bullet$ Pozitivna slika struke

3 - Relatives' recommendation $\bullet$ Preporuka rodbine

4 - Friends' recommendation - Preporuka prijatelja

5 - Family business $\bullet$ Obiteljski posao

6 - Financial advantages $\bullet$ Financijska prednost

7 - Other $\bullet$ Ostalo (please explain $\bullet$ molim, objasnite)

2. Are you still motivated to study Dentistry? (3rd and 5th year students) •

Jeste li još uvijek motivirani za studij stomatologije? (treća i završna godina)
$0-$ yes $\bullet$ da
$1-$ no $\bullet$ ne
2 - I don't know $\bullet$ ne znam

3. Do you think that you have made an improper choice? (3rd and 5 th year students) $\bullet$

Mislite li da ste loše izabrali? (treća i završna godina)

$$
\begin{aligned}
& 0 \text { - yes } \bullet \text { da } \\
& 1-\text { no } \bullet \text { ne } \\
& 2-\text { I don't know } \bullet \text { ne znam }
\end{aligned}
$$

4. Would you like to change your choice at this moment? (3 $\mathrm{rd}$ and 5 th year students) •

Želite li promijeniti svoj izbor u ovom trenutku? (treća i završna godina)

$$
\begin{aligned}
& 0 \text { - yes } \bullet \text { da } \\
& 1 \text { - no } \bullet \text { ne } \\
& 2 \text { - I don't know } \bullet \text { ne znam }
\end{aligned}
$$

If your answer is YES, explain why you would like to change $\bullet$ Ako je vaš odgovor DA, objasnite zašto biste promijenili studij:

A) It is not profitable any more (too much work for too little money) $\bullet$ Nije više profitabilan (previše posla za premalo novca)

B) Low rating of dentists in the country • Stomatologija je loše rangirana u zemlji

C) There are too many dentists $\bullet$ Previše je stomatologa

D) There is no professional perspective $\bullet$ Ne postoji perspektiva u struci

5. Is there a need for any of the following to improve your dental education and raise your motivation? (3rd and 5th year students) • Može li nešto od navedenoga pomoći da se poboljša edukacija na fakultetu i povećati motivaciju za studiranje stomatologije? (treća i posljednja godina)

0 - better organization $\bullet$ bolja organizacija

1 - more clinical practice with patients $\bullet$ više kliničke prakse s pacijentima

2 - special books for dental students $\bullet$ posebni udžbenici za studente

3 - better theoretical lectures $\bullet$ više teoretskih predavanja

4 - nothing $\bullet$ ništa

5 - Other $\bullet$ ostalo (please explain $\bullet$ molim, objasnite) 
translation method, with the assistance of colleagues who had previously undertaken questionnaire studies. First, it was translated by a professional translator, familiar with dental vocabulary and semantics together with a dentist with an excellent knowledge of Macedonian. This translation was revised by four dentists with an excellent knowledge of Macedonian. All translators worked independently. The translations were merged into one version. The final version was then back translated into original language by another professional translator, together with the dentist with an excellent knowledge of Macedonian. The back-translation was then evaluated by a native speaker who compared it with the original version. Prior to back translation, a pilot study was performed within 30 patients to test the clarity of the questions in both languages.

The backward-forward method was used to try to eliminate any discrepancies between the content and the meaning of the original and translated versions. A few relatively insignificant inconsistencies were found when the initial translation was matched with back translation, and they were considered to provide reliable evidence of the robustness of the questionnaire.

The respondents were asked to identify factors influencing the choice for applying to the faculty and seven possibilities (parents pressure, positive image, relatives' recommendation, friends' recommendation, family business, financial advantages, other) were given. The students from the third and final years were asked if they were still motivated to study dentistry, if they feel that they had made the wrong choice concerning a profession and if they wish to move to another dental school. The questions were in various forms: the second, third and fourth questions offered three possible answers (yes, no, don't know). The fifth question was about dental education and referred to any perceived need to improve it (Figure 1).

The resulting data were entered in SPSS version 17 and were analyzed using descriptive statistics. The differences between the countries and the study years among groups were tested by using the chi-square test.

\section{Results}

The response rates (numbers and percentages of students completing the questionnaire) are shown in Table 1 . The total of all students who responded was 739 dental students. In Albania/Tirana ( $\mathrm{n}=319)$, in Croatia/Zagreb $(\mathrm{n}=211)$ and in the Republic of Macedonia/Skopje ( $\mathrm{n}=209)$. The sample structure is presented in Table 2.

The responses from first, third and the last year dental students to the question regarding their main motive for the career choice are presented in Table 3. The differences in the Chi square test results for independent groups for the responses of first-year students of all three schools were statistically significant $\left(\chi^{2}=82.65 ; p<.01\right)$ suggesting that the first year dentistry students differed with regards to the motivation for choosing what to study when they started with their studies. There were significant differences between the schools in Zagreb and Skopje $\left(\chi^{2}=18.12 ; p<.01\right.$, although their distri- makedonski. Taj je prijevod revidiralo četvero stomatologa, izvrsnih poznavatelja makedonskog jezika. Svi su prevoditelji radili neovisno. Prijevodi su spojeni u jednu konačnu verziju. Zatim ju je drugi profesionalni prevoditelj preveo na izvorni makedonski jezik, zajedno sa stomatologom s izvrsnim poznavanjem makedonskoga jezika. Nakon toga je povratni prijevod procijenio izvorni govornik koji ga je usporedio s izvornikom. Prije povratnoga prijevoda provedena je pilot -studija u kojoj je sudjelovalo 30 studenata radi provjere jasnoće pitanja na oba jezika.

Metoda naprijed-natrag korištena je za pokušaj uklanjanja razlika između sadržaja i značenja izvorne i prevedene inačice. Za nekoliko relativno beznačajnih nedosljednosti koje su pronađene kada se početni prijevod izjednačio s povratnim prijevodom, smatralo se da pružaju pouzdane dokaze o robusnosti upitnika.

Ispitanici su zamoljeni da utvrde čimbenike koji utječu na njihov izbor fakulteta i ponuđeno im je sedam mogućnosti (pritisak roditelja, pozitivna slika, preporuka rodbine, preporuka prijatelja, obiteljski posao, financijske prednosti i drugo). Studente treće i završne godine dodatno se pitalo o njihovoj motivaciji za nastavak studija, smatraju li da su učinili pogrešan izbor u vezi s profesijom i žele li se prebaciti na neki drugi fakultet. Pitanja su bila u različitim oblicima: drugo, treće i četvrto pitanje nudilo je tri moguća odgovora (da, ne, ne znam). Peto pitanje odnosilo se na stomatološku edukaciju i potrebu za njezinim poboljšanjem (slika 1.).

Dobiveni podatci uneseni su u program SPSS $17 \mathrm{i}$ analizirani korištenjem deskriptivne statistike. Razlike između zemalja i godina studija testirane su Chi-kvadrat testom.

\section{Rezultati}

Brojevi i postotci studenata koji su ispunili upitnik nalaze se u tablici 1. Ukupno je anketirano 739 studenata u Albaniji/u Tirani $(\mathrm{n}=319)$, u Hrvatskoj/u Zagrebu $(\mathrm{n}=$ 211) i u Republici Makedoniji/u Skoplju (n = 209). Struktura uzorka nalazi se u tablici 2 .

Odgovori studenata stomatologije prve, treće i završne godine na pitanje o njihovu glavnom motivu za odabir karijere, prikazani su u tablici 3. Razlike u rezultatima Chi-kvadrat testa za neovisne skupine za odgovore studenata prve godine svih triju škola bile su statistički značajne $(\chi 2=82,65$; $\mathrm{p}<, 01)$, što sugerira da su se studenti prve godine stomatologije razlikovali kad je riječ o motivaciji za odabir onoga što će studirati kad su se upisali na studij. Postoje značajne razlike između fakulteta u Zagrebu i Skoplju $(\chi 2=18,12$; $p<$ 0,01 ), iako je njihova distribucija mnogo sličnija u usporedbi s distribucijom na fakultetu u Tirani. Najveća razlika bila 
Table 1. Response Rates

Tablica 1. Postotak odgovora

Dental School • Stomatološki fakultet

Albania -Tirana $\bullet$ Albanija -Tirana

Croatia - Zagreb $\bullet$ Hrvatska - Zagreb

North Macedonia - Skopje • Sjeverna Makedonija - Skoplje

\begin{tabular}{|c|c|c|}
\hline $\mathbf{1}^{\text {st }}$ year $\bullet \mathbf{1}$ godina & 3rd year $\bullet$ treća godina & Final year $\bullet$ završna godina \\
$91 / 170=53 \%$ & $110 / 119=92$ & $118 / 129=91 \%$ \\
\hline $59 / 113=52.2 \%$ & $85 / 114=75.4 \%$ & $67 / 112=59.8 \%$ \\
\hline $91 / 97=93.8 \%$ & $62 / 85=72.9 \%$ & $56 / 71=78.9 \%$ \\
\hline
\end{tabular}

Table 2. Sample structure: dental school, gender and year of study (n and \% of the total)

Tablica 2. Struktura uzorka: fakultet, spol i godina studija (n i \% ukupni)

\begin{tabular}{|c|c|c|c|c|c|}
\hline \multirow{2}{*}{ School $\bullet$ Fakultet } & \multirow{2}{*}{ Gender $\bullet$ Spol } & \multicolumn{3}{|c|}{ Year of study $\bullet$ Godina studija } & \multirow{2}{*}{ Total $\bullet$ Ukupno } \\
\hline & & $1 s t$ & 3rd & Final & \\
\hline \multirow{2}{*}{ Skoplje } & Female $\bullet$ Ženski & $34(16.3)$ & $31(14.8)$ & $26(12.4)$ & $91(43.5)$ \\
\hline & Total $\bullet$ Ukupno & $91(43.5)$ & $62(29.7)$ & $56(26.8)$ & $209(100)$ \\
\hline \multirow{3}{*}{ Tirana } & Female $\bullet$ Ženski & $35(11.0)$ & $46(14 .)$. & $40(12.5)$ & $121(37.9)$ \\
\hline & Male• Muški & $56(17.6)$ & $64(20.1)$ & $78(24.5)$ & $198(62.1)$ \\
\hline & Total $\bullet$ Ukupno & $91(28.5)$ & $110(34.5)$ & $118(37.0)$ & $319(100)$ \\
\hline \multirow{3}{*}{ Zagreb } & Female $\bullet$ Ženski & $12(5.7)$ & $18(8.5)$ & $20(9.5)$ & $50(23.7)$ \\
\hline & Male • Muški & $47(22.3)$ & $67(31.8)$ & $47(22.3)$ & $161(76.3)$ \\
\hline & Total $\bullet$ Ukupno & $59(28.0)$ & $85(40.3)$ & $67(31.8)$ & $211(100)$ \\
\hline
\end{tabular}

Table 3. Motives for career choice of dental students from the three schools in different academic years

Tablica 3. Motivi za izbor karijere kod studenata s triju fakulteta na različitim godinama studija

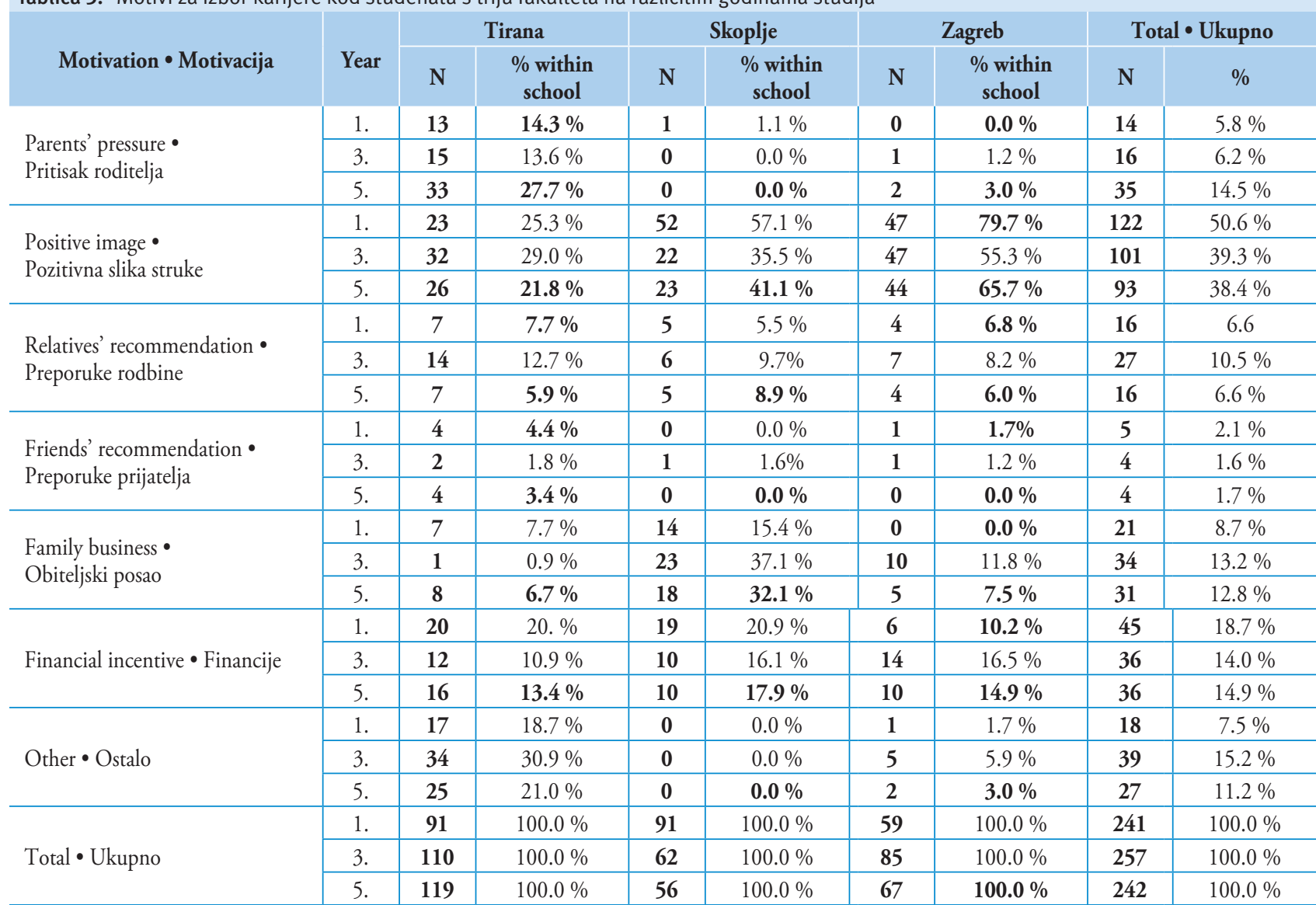

bution is much more alike than the distribution in the dental school in Tirana. The most striking difference was in the response to the question parents' pressure which was reported by 13 of students from Tirana (14\%), none from Zagreb and only one from Skopje. On the other hand, positive image was je u odgovorima na pitanje o pritisku roditelja koji je prijavilo 13 studenata iz Tirane (14\%), ni jedan iz Zagreba i samo jedan iz Skoplja. S druge strane, pozitivna slika struke bio je najčešći odgovor u Zagrebu. Odgovori iz svih zemalja bili su uglavnom slični s obzirom na učestalost kojom je preporuka 
the most frequent response by students from Zagreb. The responses from all countries were broadly similar with regards to frequencies with which relatives' recommendation was reported as a motive for choosing to study dentistry.

There were significant differences among all 3 schools within the 3 rd year of study $\left(\chi^{2}=99.74 ; p<.01\right)$, although the most frequent findings for all groups was the positive image of the profession. The differences were significant across all comparisons (Skopje-Zagreb; $\chi^{2}=17.59 ; p<.01$ ) (Skopje-Tirana; $\left.\chi_{i}^{2}=66,52 ; p<.01\right)$ (Zagreb-Tirana; $\chi^{2}=44,37 ; p<.01$ ). The same difference was found among all final year students $\left(\chi^{2}=94.35 ; p<.01\right)$. All responses from the three schools differed (Skopje-Zagreb; $\chi^{2}=17.20 ; \quad p<.01$ ) (Skopje-Tirana; $\left.\chi^{2}=51,77 ; p<.01\right)$ (Zagreb-Tirana; $\left.\chi^{2}=47,77 ; p<.01\right)$.

Additionally, with few exceptions, the pattern of frequencies of answers was similar to that of the 1st year students. The most striking exception to the answers collected from the 1st year students was the percentage of final year students from the dental school in Tirana who reported that a positive image as a motive for studying was higher than in the 1 st year of study.

When the responses are compared with regards to the Croatian dental school, there are only two categories in which respondents from the $3^{\text {rd }}$ study year were similar to those in the two dental schools from Skopje and Tirana. They were positive image and friends' recommendation. Financial incentive as motivation to study dentistry was relevant for only $16.1 \%$ 3rd year students from Skopje, which was almost the same as that for the students from Zagreb (16.5\%)(Table 3).By the final year, the pattern of similarities and dissimilarities between the school in Zagreb, Skopje and Tirana respondents was similar, suggesting that students differ mostly in respecting their parents' wish (more typical for students from Tirana, 27.1\%). Except for the students from Skopje, the vast majority students at the other two dental schools reported that they were still well motivated to continue with their studies (Figure 2). A far higher percentage of third year dental students from Skopje (33.9\%), than at Tirana (11.8\%) and Zagreb $(2.4 \%)$ reported that they were not motivated to finish their dental studies. As could be expected, the general pattern was that, the higher the study year, the higher was the motivation to graduate (Figure 3) from the school and start working as a dentist. The reasons for dissatisfaction with dental courses were reported by only 58 students from both third and final year of studies. Students in all three dental schools reported that they would like to have more clinical practice with patients (Figure 4). The second most frequently chosen aspect was better organization of the studies in terms of timing, guidance and so on. The highest percentage of students who thought that their instructors should improve the quality of teaching was among the final year students from $\mathrm{Za}$ greb (9\%), while none of the students from Skopje reported this. On the other hand, final-year students from Skopje were those who most frequently reported that they felt that nothing should be changed in the way their studies were organized and delivered (Figure 4). rodbine istaknuta kao motiv za odabir studija stomatologije.

Bilo je značajnih razlika između svih triju fakulteta unu$\operatorname{tar} 3$. godine studija $(\chi 2=99,74 ; \mathrm{p}<.01)$, iako je za sve skupine najčešći odgovor bio pozitivan ugled profesije. Razlike su bile značajne u svim usporedbama između država (Skoplje - Zagreb; $\chi 2=17,59 ; \mathrm{p}<.01$ ) (Skoplje - Tirana; $\chi 2 \mathrm{i}=66,52$; $\mathrm{p}<.01$ ) (Zagreb - Tirana; $\chi^{2}=44,37 ; \mathrm{p}<.01$ ). Isto je pronađeno među svim studentima završnih godina studija $(\chi 2$ $=94,35 ; \mathrm{p}<., 01)$. Svi odgovori iz triju škola su se razlikovali (Skoplje - Zagreb; $\chi^{2}=17,20 ; \mathrm{p}<$.01) (Skoplje - Tirana; $\left.\chi^{2}=51,77 ; \mathrm{p}<.01\right)$ (Zagreb - Tirana; $\left.\chi 2=47,77 ; \mathrm{p}<.01\right)$.

Uzorak učestalosti odgovora, uz nekoliko iznimaka, bio je kao kod studenata prve godine. Najveća razlika u odnosu prema odgovorima studenata prve godine bila je u postotku studenata završne godine u Tirani koji su istaknuli da je za njih pozitivna slika kao motiv za studij veća negoli na prvoj godini studija. Kada se odgovori usporede $s$ hrvatskim fakultetom, samo su u dvjema kategorijama ispitanici treće godine bili slični studentima u Skoplju i Tirani - to su pozitivna slika i preporuka prijatelja. Financijski poticaj kao motivacija za studij stomatologije bio je relevantan za samo 16,1 \% studenata treće godine u Skoplju, što je gotovo jednako kao i kod zagrebačkih studenata (16,5 \%) (tablica 3.). Do posljednje godine obrazac odgovora među ispitanicima u Zagrebu, Skoplju i Tirani bio je sličan, što sugerira da se studenti uglavnom razlikuju prema tome poštuju li želje svojih roditelja (što je tipičnije za one iz Tirane - 27,1\%). Osim studenata iz Skoplja, velika većina studenata na drugim dvama fakultetima istaknula je da su još uvijek dobro motivirani za nastavak studija (slika 2.). Mnogo više studenata stomatologije treće godine iz Skoplja (33,9 \%), negoli iz Tirane $(11,8$ $\%$ i Zagreba (2,4\%), odgovorilo je da nisu motivirani za završetak studija. Kao što se moglo i očekivati, opći je obrazac da što je viša godina studija, to je veća i motivacija za stjecanje diplome (slika 3.). Razloge za nezadovoljstvo edukacijom prijavilo je samo 58 studenata treće i završne godine studija. Studenti svih triju fakulteta istaknuli su da bi željeli imati više kliničke prakse s pacijentima (slika 4.). Drugi najčešće odabrani odgovor odnosio se na bolju organizaciju studija, kad je riječ o vremenu, uputama za rad itd. Najveći postotak studenata koji su smatrali da bi nastavnici trebali poboljšati kvalitetu nastave bio je među zagrebačkim studentima završnih godina (9\%), a o toj se temi u Skoplju nitko nije izjasnio. S druge strane, studenti završnih godina iz Skoplja su, u usporedbi $s$ drugim gradovima, najčešce odgovorili da smatraju kako se ništa ne smije mijenjati u načinu organiziranja i provođenju studija (slika 4.). 


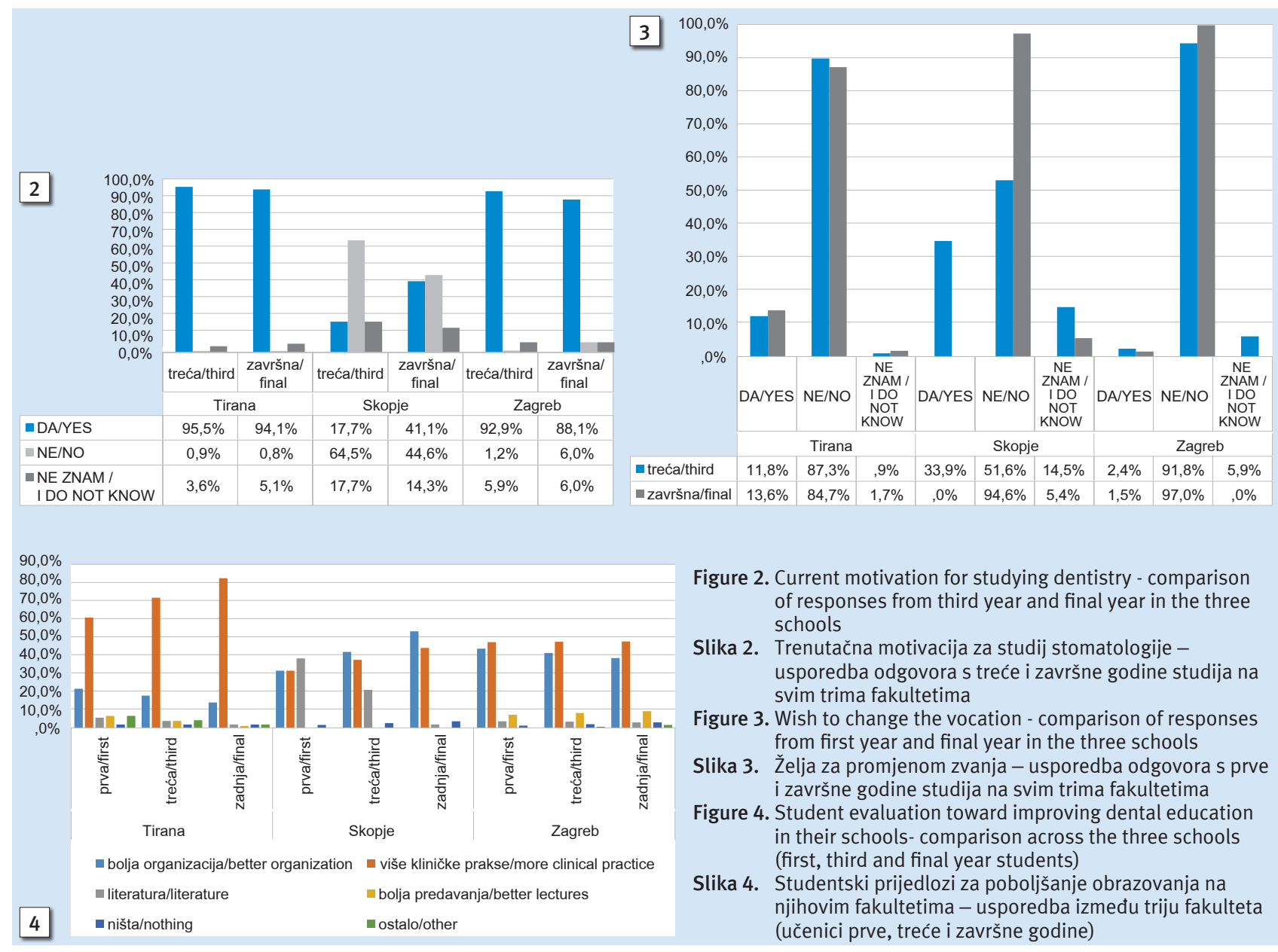

\section{Discussion}

One of the biggest public dental schools from three selected South Eastern European countries were chosen to participate in this study. Students from 1st, 3rd and the final year were chosen to participate in the study; first group, who were just starting their studies, to assess their motivation to study dentistry, the second group, who were half way through the course, to confirm if their professional choice was good or they had been disappointed, and the third group, who were very near to the end of their studies, to assess their satisfaction with education and their future career. Numerous studies in many countries have described the reasons for choosing dentistry as a profession $(19,20,21)$. Most of the investigations have been questionnaire based and have used different instruments which means that the findings are not directly comparable (18). In the current study, the same questionnaire was used in all three countries. The results show that the most frequent reason for applying for dental studies at the three dental schools was the positive image of dental profession. Only for the final year students at Tirana the reason was parental pressure as the most important motive for choosing to study dentistry, also showing the influence of family on children decisions. Positive image for dental profession is mostly connected with the better social position in the society, making it a more desirable job. At all three schools, financial incentive was reported as the second most common

\section{Rasprava}

U ovom istraživanju sudjelovali su najveći državni fakulteti iz triju odabranih zemalja jugoistočne Europe. Studenti 1., 3. i završne godine izabrani su na sljedeći način - u prvoj skupini bili su oni koji su tek upisali studij kako bi se procijenila njihova motivacija za studij stomatologije; u drugu skupinu uvršteni su oni na polovini studija kako bi potvrdilo je li njihov profesionalni izbor bio dobar ili su se razočarali; u trećoj skupini bili su studenti vrlo blizu kraja studija kako bi procijenilo njihovo zadovoljstvo obrazovanjem i budućom karijerom. U brojnim studijama u mnogim zemljama opisani su razlozi za odabir stomatologije kao profesije $(19,20,21)$. Većina istraživanja temelji se na upitnicima i primjenjuju se različiti instrumenti, što nam onemogućuje usporedbu podataka (18). U ovoj studiji isti je upitnik korišten u svim zemljama. Rezultati pokazuju da je najčešći razlog za upis na stomatološki studij na svim trima fakultetima bila pozitivna slika profesije. Samo za studente završne godine u Tirani roditeljski je pritisak bio najvažniji motiv za izbor stomatologije, što je također pokazalo snažan utjecaj obitelji na odluke adolescenata. Pozitivna slika stomatološke profesije uglavnom je povezana s boljim socijalnim položajem u društvu, što ga čini poželjnijim poslom. Na svim trima fakultetima financijski poticaj istaknut je kao drugi najčešći razlog za odabir stomatologije, ističući njegovu važnost u svakodnevnom odlučivanju. 
reason for choosing dentistry, underlining its importance in everyday decision making.

Just to give a broader overview, we have to compare the results of this study with similar ones all around the globe In contrast to our findings, a study in Australia reported that the most predominant motives for students were to serve others, to become independent, to enjoy job satisfaction, and to acquire financial security. (22). Similar results were reported in Canada, Thailand, and Japan (helping people, health carerelated occupation, and academic interest for studying dentistry) $(23,24)$. These motives are different, showing a strong social awareness to help others, not only thinking about individual prosperity and social position.

Regarding motivation towards career choice, $41 \%$ of Japanese students stated positive motives related to helping others, achieving self-worth and health-care related interests.

Regarding motivation towards career choice, $41 \%$ of Japanese students indicated positive motives related to helping others, achieving self-worth and health-care related interests.

Regarding motivation towards career choice, $41 \%$ of Japanese students stated positive motives related to helping others, achieving self-worth and health-care related interests.

Regarding motivation towards career choice, $41 \%$ of Japanese students stated positive motives related to helping others, achieving self-worth and health-care related interests,

We have found the results similar to the ones of this study in India; the main factors for choosing dentistry as a profession have been reported as: parents' influence, reputation and better lifestyle and $96.7 \%$ of students reported these factors as motivational. They considered that dentistry was a highly prestigious profession and wished to go to dental schools to become ethical, skilled professionals capable of practicing dentistry at such a level that was consistent with the expectations of society $(25,26)$. In another study Chinese dental students indicated that their choice was mainly because of financial reasons or prestige (24), also supporting the self-orientated profession decision as a main motivation. In a descriptive, cross-sectional study which was conducted on a cohort of first-year dental students from thirteen countries in six continents in 2011-12, it was found that the strongest motives were a flexible work schedule, leaving time for family life, and opportunity to help those less fortunate (27). Some authors have investigated the dental profession as a career choice by different ethnic groups. One group presented data on the persons who influenced the selection of dentistry as a career by students belonging to different ethnic groups in Australia and New Zealand. It was reported that parents, in particular the mother, were more influential among Asian students than among Anglo-Australian or New Zealand students (28)

While a positive image for dental profession was connected with the better social position in the society in some countries, in other countries a positive image for dentistry has been connected with the desire to offer help to people. This could be explained by the low socioeconomic situation in south-eastern European countries where an individual has to think about his/her social and financial position, while in more developed parts of the world financial security gives the
Samo da bismo dali širi pregled, moramo usporediti rezultate ove studije sa sličnima u svijetu. Suprotno našim rezultatima, jedno istraživanje u Australiji pokazalo je da je motivacija studentima pomaganje drugima, da postanu neovisni, da uživaju i da su zadovoljni poslom te da steknu financijsku sigurnost. (22). Slični rezultati zabilježeni su u Kanadi, Tajlandu i Japanu (pomaganje ljudima, zanimanje vezano za zdravstvenu zaštitu i akademsko zanimanje za studij stomatologije) $(23,24)$. Ti su motivi različiti, pokazuju snažnu društvenu usmjerenost na pomoć drugima, ne misleći samo na osobni prosperitet i socijalni položaj.

U Indiji smo pronašli rezultate slične onima iz našeg istraživanja - glavni razlozi za odabir stomatologije kao profesije navode se utjecaj roditelja, ugled i bolji način života, a istaknulo ih je 96,7 \% studenata kao glavne motivacijske čimbenike. Smatraju da je stomatologija vrlo ugledna profesija i žele se upisati na taj studij kako bi postali etični, kvalificirani profesionalci sposobni da se bave strukom na razini koja je u skladu s očekivanjima društva $(25,26)$. U drugoj studiji kineski su studenti stomatologije naveli da je njihov izbor bio uglavnom financijske prirode ili radi prestiža (24). U poprečno-presječnom (cross-sectional) istraživanju provedenom među studentima prve godine iz trinaest zemalja na šest kontinenata u razdoblju od 2011. do 2012., utvrđeno je da su najjači motivi bili fleksibilan raspored rada koji ostavlja vremena za život u obitelji i mogućnost da se pomogne osobama koje nemaju tu opciju (27). Neki autori istraživali su zubarsku profesiju kao izbor karijere u različitim etničkim skupinama - primjerice, jedno istraživanje uspoređivalo je razlike među studentima različitih etničkih skupina u Australiji i Novom Zelandu. Istaknuto je da su roditelji, posebno majke, bile utjecajnije među azijskim studentima negoli među angloaustralskim ili novozelandskim (28).

Iako je pozitivna slika stomatološke profesije u nekim zemljama bila povezana $s$ boljim socijalnim položajem u društvu, u drugima je povezana ponajprije sa željom da se pomogne drugim ljudima. To bi se moglo objasniti niskom socijalno-ekonomskom situacijom u zemljama jugoistočne Europe u kojima pojedinac mora razmišljati o svojem socijalnom i financijskom položaju, dok se u razvijenom i financijski sigurnom dijelu svijeta studentu pruža mogućnost izbora stomatologije kao profesije koja je usmjerena na pacijenta.

Pozitivna slika stomatološke profesije bila je glavni razlog učenicima da se upišu na stomatologiju na svim trima fakultetima. U Hrvatskoj, članici Europske unije (EU), taj je postotak najviši ( $97 \%$ studenata na završnoj godini). U dvjema državama koje nisu članice EU (Albanija, Sjeverna Makedonija), činilo se da stomatološka profesija nema dobar status, a očekivanja studenata se ne ostvaruju, posebno u Skoplju (čak $33,9 \%$ spremno je promijeniti zvanje, a do 64,5\% izgubilo je motivaciju za studij).

Da bismo objasnili to stanje, moramo spomenuti socijalno-ekonomsku pozadinu. Takva situacija može biti zbog niskih prihoda stomatologa koji rade u privatnoj praksi u Makedoniji i njihov velik broj u odnosu prema stanovništvu. U zemljama koje nisu članice EU-a, moraju se primijeniti strategije za ograničavanje broja studenata, jer mnogi neće na- 
student opportunity to choose dentistry as a profession that is patient-oriented.

A positive image of the dental profession was the main reason for students studying dentistry at all three schools. In Croatia, a member of the European Union (EU), this percentage is the highest one; $97 \%$ of the students of the final year. In the two non-EU countries (Albania, North Macedonia) it seemed that the dental profession does not have good status and student expectations are not being fulfilled, especially in Skopje (up to 33.9\% willing to change their vocation and up to $64.5 \%$ lost their motivation to study).

To explain this situation, we have to mention the socioeconomic background. This situation might reflect the low income of dentists working in private practices in Macedonia and a large number of the dentists, relative to the overall population. In non-EU countries strategies to limit the number of students have to be implemented, since a large number of them cannot find a job at the end of their studies and, therefore, are not motivated to study while they are dental students.

One of the strategies to improve the situation could be to organize the study in a better way, by giving more attention to students' suggestions. The main thing to improve is to include more clinical practice and to better organize the study. Better textbooks, more recent literature and better lectures were stated as important parts of improvement, however, not on the main list.

The results of this study could be used in a much broader study in Europe, in order to compare with the students from the European countries which have different political, social and healthcare cultures and systems. The results could be observed through socioeconomic and cultural differences underlining European diversities.

\section{Conclusions}

This study has highlighted that a positive image of dental profession was the main factor for students' pursuing dentistry in the three south-eastern European dental schools that took part in the current study. The positive image for the profession was still present in the final year of study for dental students from Tirana and Zagreb but not for dental students from Skopje, whose motivation to study dentistry decreased as dental courses progressed. These data are a valuable addition to similar data collected worldwide, to compare reasons to study dentistry between different countries, with different social, economic and cultural backgrounds.

\section{Ethics approval and consent to participate}

Ethics approval for this study was obtained from the Ethics Committee at the Faculty of Dental Medicine, University Ss. Cyril and Methodius in Skopje, North Macedonia.

The informed consent obtained from study participants was verbal. At the beginning of the questionnaire the students were informed about the aim of the study, that participation was voluntary and confidentiality was assured.

\section{Competing Interests}

The authors report that they have no conflict of interests. ći posao na kraju studija i zato prestaju biti motivirani da ga završe.

Jedna od strategija za poboljšanje stanja mogla bi biti organiziranje studija na bolji način i da pritom poslušamo što predlažu studenti. Najvažnije što bi trebalo učiniti jest uključivanje više kliničke prakse i poboljšanje organizacije. Literatura i bolja predavanja također su važan dio poboljšanja, ali nisu među glavnim studentskim prijedlozima.

Rezultati ove studije mogli bi se upotrijebiti u znatno široj studiji u Europi za usporedbu studenata iz više europskih zemalja s različitim političkim i socijalnim sustavima te zdravstvenom kulturom. Rezultati se mogu promatrati na temelju društveno-ekonomskih i kulturnih razlika koje ističu europsku raznolikost.

\section{Zaključci}

Ova studija istaknula je pozitivnu sliku stomatološke struke kao glavni motivacijski i čimbenik za studij na svim trima fakultetima jugoistočne Europe koji su sudjelovali u istraživanju. Pozitivna slika profesije bila je zabilježena je i na posljednjoj godini studija kod studenata stomatologije iz Tirane i Zagreba, ali ne i iz Skoplja, gdje je tijekom studija motivacija opadala. Ovi podatci vrijedan su dodatak sličnim podatcima prikupljenima diljem svijeta za usporedbu motiva za studij stomatologije između različitih zemalja s različitim socijalnim, ekonomskim i kulturnim okružjem.

\section{Etičko odobrenje i pristanak na sudjelovanje}

Etičko odobrenje za ovo istraživanje pribavljeno je od Etičkog povjerenstva Stomatološkog fakulteta Sveučilišta sv. Ćirila i Metoda u Skoplju, Sjeverna Makedonija.

Informirani pristanak dobiven od sudionika bio je usmen. Na početku sudjelovanja studenti su obaviješteni o cilju istraživanja, da je sudjelovanje dobrovoljno i da se poštuje povjerljivost.

\section{Sukob interesa}

Autori navode da nisu bili u sukobu interesa. 


\section{Acknowledgments}

The authors are thankful to all students from the three countries who participate in this study.

\section{Zahvale}

Autori su zahvalni svim studentima iz triju zemalja koji su sudjelovali u ovom istraživanju.

\section{Sažetak}

Uvod: Željelo se istražiti i usporediti čimbenike koji su potaknuli studente na studij stomatologije u zemljama sličnog okružja (Albanija, Hrvatska i Republika Sjeverna Makedonija) i procijeniti je li se njihova motivacija tijekom godina promijenila ili ne. Materijal i metode: U 2014./2015. godini provedena su poprečno-presječna istraživanja (cross-sectional) na državnim stomatološkim fakultetima u Tirani (Albanija), Zagrebu (Hrvatska) i Skoplju (Makedonija) kako bi se procijenilo stajalište studenata o njihovoj motivaciji za karijeru. Dobrovoljno i anonimno sudjelovali su studenti stomatologije s prve, treće i završne godine. Upitnik s pet stavki preveden je na jezike zemalja sudionica. Etičko odobrenje dalo je Etičko povjerenstvo Sveučilišta sveti Ćiril i Metod iz Skoplja. Chi kvadrat testom ispitano je postoje li statistički značajne razlike u odgovorima između studenata u trima državama i između godina studija. Rezultati: Ukupno je bilo uključeno 739 ispitanika (319 u Tirani, 211 u Zagrebu i 208 u Skoplju). Razlike u odgovorima studenata prve godine u svim trima zemljama bile su statistički značajne ( $X 2$ $=82,65 ; \mathrm{p}<0,01)$. Najintrigantnije je bilo pitanje o pritisku roditelja da studiraju stomatologiju na koje je najviše pozitivnih odgovora bilo u Tirani (čak 27,7 \%). Pozitivna slika bio je najčešći odgovor zagrebačkih studenata (do 79,7 \%), ali se smanjuje od prve do posljednje godine u Skoplju. Također su postojale značajne razlike između fakulteta unutar trećih i posljednjih godina studija. Zaključci: Pozitivna slika stomatološke profesije bila je glavni razlog za upis na svim trima fakultetima - tako je odgovorilo čak 97 \% studenata na završnoj godini u Hrvatskoj, članici Europske unije (EU). U dvjema državama koje nisu članice EU-a (Albanija, Sjeverna Makedonija) činilo se da stomatološka profesija nema tako dobar status, a očekivanja studenata se ne ispunjavaju, posebno u Skoplju (čak 33,9\% spremno je promijeniti zvanje i njih do $64,5 \%$ izgubilo je motivaciju za studij). Jedna od strategija za poboljšanje stanja mogla bi biti uključivanje više kliničke prakse i bolja organizacija pojedinih studija.
Zaprimljen: 18. veljače 2020 .

Prihvaćen: 27. travnja 2020.

Adresa za dopisivanje izv. prof. Nikola Petričević Sveučilište u Zagrebu Stomatološki fakultet Gundulićeva 5, 10.000 Zagreb, Hrvatska petricevic@sfzg.hr

\section{Ključne riječi}

studenti dentalne medicine; izbor karijere; motivacija; jugoistočna Europa

\section{References}

1. Gallagher J, Clarke W, Wilson N. Understanding the motivation: A qualitative study of dental students' choices of professional career. Eur J Dent Educ. 2008 May;12(2):89-98.

2. Halawany H. Career Motivations, Perceptions of the Future of Dentistry and Preferred Dental Specialties among Saudi Dental Students. Open Dent J. 2014 Sep 8;8:129-35.

3. Waylon A, Barnes O, Kenyon P. Neville P. Can motivations for studying dentistry inform us about gender and BME differences in dental academic careers? Br Dent J. 2017 Feb 24;222(4):245249.

4. Hawley N, Ditmyer N, Sandoval V. Predental students' attitudes towards and perceptions of the dental profession. J Dent Educ. 2008 Dec;72(12):1458-64.

5. Khami M, Murtomaa H, Jafarian M, Vehkalahti M, Virtanen J. Study motives and career choices of Iranian dentists. Med Princ Pract. 2008;17(3):221-6.

6. Karibe H, Kawakami T, Suzuki A et al. Career choice and attitudes towards dental education among dental students in Japan and Sweden. Eur J Dent Educ. 2009 May;13(2):80-6.

7. Crossley M, Mubarik A. A comparative investigation of dental and medical students' motivation towards career choice. $\mathrm{Br}$ Dent J. 2002 Oct 26;193(8):471-3.

8. Gallagher J E, Patel R, Wilson N H. The emerging dental workforce: why dentistry? A quantitative study of final year dental students' views on their professional career. BMC Oral Health. 2007 Jun $15 ; 7: 7$.

9. Brand AA, Chikte UM, Thomas CJ. Choosing dentistry as a career: a profile of entering students (1992) to the University of Sydney, Australia. Aust Dent J. 1996 Jun;41(3):198-205.

10. NikolovskaJ, Mancevska S, Kapusevska B, Popovska L, Mindova S. An Assessment of Career Satisfaction among Macedonian Dentists. Contributions, Section of Medical Science 2014; Contributions, Section of Medical Science 2014; XXXV 1: 255-261.

11. Nikolovska J. Oral Health Care Provision Systems in the Black Sea Countries. Part 14: The Republic of Macedonia. OHDM 2013; 12(2): 61- 64.

12. Orenuga O, Da Costa O. Characteristics and Study Motivation of Clinical Dental Students in Nigerian Universities. J Dent Educ. 2006 Sep;70(9):996-1003.

13. Gietzelt D. Social profile of first-year dentistry students at the University of Sydney. Aust Dent J. 1997 Aug;42(4):259-66.

14. Zadik D, Gilad R, Peretz B. Choice of dentistry as a career and perception of the profession. J Dent Educ. 1997 Oct;61(10):813-6.

15. Scarbecz M, Ross J. Gender differences in first-year dental stu- dents' motivation to attend dental school. I Dent Educ. 2002 Aug;66(8):952-61.

16. Stewart FMJ, Drummond JR, Carson L, Reddick GH: The future of the profession - a survey of dental school applicants. Br Dent J. 2004 Nov 13;197(9):569-73; quiz 577.

17. Vigild M, Schwarz E: Characteristics and study motivation of Danish dental students in a longitudinal perspective. Eur J Dent Educ. 2001 Aug;5(3):127-33.

18. Gallagher J, Clarke W, Eaton K, Wilson N. Dentistry - a professional contained career in healthcare. A qualitative study of Vocational Dental Practitioners' professional expectations. BMC Oral Health. 2007 Nov 16;7:16.

19. Musa ME, Bernabe E, Gallagher JE. Students' motivation to study dentistry in Malaysia: an analysis using confirmatory factor analysis. Hum Resour Health 2015,13:47.

20. Belsi A, Asimakopoulou K, Donaldson N, Gallagher J. Motovation to study dental professions in one London Dental Institute. Eur J Dent Educ. 2014 Feb;18(1):24-30.

21. Rashid H, Manoharan A, Abufanas S, Gallagher JE. Motivation for a career in dentistry: the views of dental students in the United Arab Emirates. Int Dent J. 2013;63(5):259-265.

22. Mariño R, Au-Yeung W, Habibi E, Morgan M. Sociodemographic Profile and Career Decisions of Australian Oral Health Profession Students. J Dent Educ. 2012 Sep;76(9):1241-9.

23. Karibe H, Suzuki A, Sekimoto T, Srithavaj T. et al. Cross-Cultural Comparison of the Attitudes of Dental Students in Three Countries. J Dent Educ. 2007 Nov;71(11):1457-66.

24. Yan X, Zhang X, Jinno Y, Tachibana K, Gao J, Koyano K, Ai H, Shen $Y$. Career choice and future design of dental students in China and Japan. Int Dent J. 2014 Apr;64(2):68-75.

25. Motghare V, Jayaprakash K, Shivalingesh KK, Gupta B, Thakkar S, Prabhakar I. Sociodemographic profile and future expectations of newly entered students in a dental institute in Greater Noida, India. J Indian Assoc Pub Hlth Dent. 2015; 13:67-72.

26. Aggarwal A, Mehta S, Gupta D. Dental students' motivations and perceptions of dental professional career in India. I Dent Educ 2012;76:1532-1539.

27. Du Toit J, Jain S, Montalli V, Govender U. Dental Students' Motivations for Their Career Choice: An International Investigative Report. J Dent Educ. $2014 \mathrm{Apr} ; 78(4): 605-13$.

28. Mariño R, Morgan M, Winning T, Thomson M, Marshall R, Gotjamanos T, Evans W. Sociodemographic Backgrounds and Career Decisions of Australian and New Zealand Dental Students. J Dent Educ. 2006 Feb;70(2):169-78. 